\title{
PRIMACY EFFECTS AND VOTING METHODS (LITERATURE REVIEW)
}

\author{
Steven Linder* \\ University of California
}

\begin{abstract}
The primacy effect has long been considered a decisive factor in determining election outcomes and has consequently developed a robust literature dedicated to studying it in different scenarios and contexts. However, existing research has offered limited insight into how the choice of voting method, particularly by-mail voting, may influence its impact on elections by altering how and when voters participate. This article first reviews why the primacy effect exists, how researchers identify its influence, and its overall impact on election outcomes. It then discusses why the use of by-mail voting should be expected to alter the primacy effect, and analyzes two works where this relationship has been explored. Their results highlight several of the issues faced when trying to examine this relationship, but also indicate that further study is warranted and likely to be fruitful.
\end{abstract}

Key words: Electoral Systems, Election Outcomes, Ballot Design, Primacy Effects, Mail Voting.

\section{EFEKT PIERWSZEŃSTWA A RÓŻNE METODY GLOSOWANIA. PRZEGLAD LITERATURY}

Streszczenie: Efekt pierwszeństwa w decyzjach wyborczych (ang. the primacy effect) jest od dawna uwazany za kluczowy czynnik determinujacy wyniki głosowań. Mechanizm jego działania $w$ rozmaitych kontekstach zostat szczegółowo przedstawiony w licznych pracach, dotychczas jednak nie skupiono się $w$ wystarczajacym stopniu na roli efektu pierwszeństwa podczas głosowania metoda korespondencyjna. W moim artykule dokonuje przegląu czynników determinujacych występowanie efektu pierwszeństwa oraz opisuję jego znaczenie dla wyników wyborów. Następnie, analizujac wyniki dwóch prac nad efektem pierwszeństwa oraz wyborami korespondencyjnymi, rozważam, dlaczego taka forma głosowania może zwiększyć siłe działania efektu pierwszeństwa.Oma-

* Steven Linder, University of California, 3151 Social Science Plaza, Irvine, CA, e-mail: sjlinder@uci.edu 
wiane przeze mnie rezultaty identyfikuja pewne problemy zwiazane z badaniem zależności między efektem pierwszeństwa a wynikami głosowań droga korespondencyjna, jednocześnie wskazuja na kierunki dalszych obiecujacych badan nad fenomenem efektu pierwszeństwa.

Stowa kluczowe: systemy wyborcze, wyniki głosowań, karty do głosowania, efekt pierwszeństwa, głosowanie korespondencyjne.

\section{INTRODUCTION}

The electoral systems literature contains a sizable collection of works studying how the fundamental design features of ballots can influence election outcomes. Design choices such as the placement of punch-holes (Wand et. al. 2001) and ballot instructions (Kimball \& Kropf, 2005) have been found to greatly impact a voter's ability to choose their preferred candidates, or have their vote counted at all. Other studies have identified that features such as including candidate party-affiliations, or descriptive characteristics (Klein \& Baum, 2001, Matson \& Fine, 2006) subtly influence a voter's perception of alternatives by altering available heuristic information. However, the feature to receive the most attention from scholars has been on how the placement of alternatives on the ballot alters a candidate's electoral performance. Variously labelled as the primacy, name-order, or ballotposition effect, researchers have consistently shown that being listed first on a ballot, or otherwise strategically ranked, causes a direct increase in the number of votes that a candidate receives. Yet despite the number and variety of studies on the subject, researchers have generally avoided examining how the use of convenienceenhancing voting alternatives, particularly by-mail voting, may alter the scale and significance of the primacy effect.

\section{The Primacy Effect}

Studies of primacy effects commonly address three fundamental questions; why it exists, does it exist, and how much does it impact election outcomes. In theorizing why, scholars have drawn from the rational-choice literature to explain how voters rationally economizing their information gathering can sometimes result in uninformed choices. 


\subsection{Why would voters choose the first alternative on the ballot?}

In an ideal scenario, voters participating in an election would have full knowledge on the candidates and issues they are voting on, and full comprehension of the implied consequences of their choices. In reality voters rarely, if ever, have the time, resources, or engagement necessary to fully educate themselves on the numerous and variable subjects requiring their input (Bowler et. al. 1992, Verba et. al. 1995, Shugart et al. 2005). They instead attempt to maximize the returns on their information gathering by strategically concentrating their attention and resources towards subjects that are most pertinent to their interests and wellbeing (Miller \& Krosnick, 1998, Boehmke et. al. 2012). The choice of subjects is similarly biased towards high-visibility issues with plentiful media coverage such as national-level elections, or major social issues, since they are the most readily accessible (Selb, 2008, Van Erkel \& Thijssen, 2016). While this strategy ultimately helps voters conserve time and resources, it is also problematic as it frequently results in voters being confronted with choices in less salient political contests that they are not prepared to make informed decisions on.

Voters typically enter into elections under pressure to participate within a set time-frame (Bowler et. al. 1992, Koppel \& Steen, 2004). When confronted with low-information choices on the ballot, voters rely on heuristic cues such as party affiliation, platform positions, or even basic descriptive characteristics such as names and gender, to quickly choose among alternatives (Niemi \& Herrnson, 2003, Binder et. al. 2015). These cues provide voters an immediate reference point for how an alternative may behave or impact them. For example, candidates' party affiliations can help voters infer their positions on policy issues based on their party's platform (Bonneau \& Cann, 2015). However, these associations are imperfect and provide an incomplete or inaccurate depiction of candidates that can lead voters towards making choices that contradict their interests (Binder et. al. 2015, Augenblick \& Nicholson, 2016). When the heuristic aids intentionally available on a ballot are not enough for voters to overcome their lack of information, they are then pressured towards either choosing no alternative or relying on especially arbitrary evaluations to guide their decisions (Matson \& Fine, 2006, Devroe \& Wauters, 2020). The primacy effect thus comes into play when voters choose the latter option and decide out of convenience or pre-conceived assumptions of prominence to choose alternatives listed first on a ballot.

The top of a list is typically the first viewed by readers, giving information placed there a considerable advantage to being processed and remembered (Brockington, 2003, Edwards, 2015). Ranked listings frequently capitalize on this heightened visibility by placing the highest ranked, or valued, alternatives at the top to advertise their achievements or qualities (Geys \& Heyndels, 2003, Lutz, 2010). This practice occasionally sees use in some political contests as well, where incumbents or 
prominent candidates are placed first on a ballot or a party list to signal their status to readers (Niemi \& Herrnson, 2003). Other contextual factors such as the amount time a voter is willing to spend participating in an election, or their physical comfort, can also incentivize voters to make snap decisions (Darcy \& Schneider, 1989, Augenblick \& Nicholson, 2016). Reinforced by experience, common intuition, and their desire to finish participating, voters may assume that alternatives on a ballot are ranked according to some inherent quality when they are actually listed with no regard for merit or skill. This combination of intuitive factors has made the primacy effect an extremely appealing theory for otherwise contradictory patterns of voter behavior; and has long made it a target for study by researchers trying to determine its veracity.

\subsection{Does primacy effect really exist and how to estimate it?}

While scholars have come to a consensus on why the primacy effect exists in theory, they have had considerably more difficulty trying to empirically prove that its size warrants our attention. Being listed first on the ballot has long been assumed by political actors and theorists to improve electoral performance, and several early attempts were made to observe it in action (Darcy, 1986, 1998, Miller \& Krosnick, 1998). However, it was not until the late $20^{\text {th }}$ century that researchers began to find success in empirically exploring the validity of this common assumption, and if so, what were its causes. Scholars quickly found out that unavoidable institutional obstacles prevented them from directly observing primacy effects in a controlled setting (Edwards, 2015).

As a critical component of elections, and a traditional target for manipulation by political interests, democratic states universally maintain strict control over the design, creation, and distribution of ballots (Darcy \& Schneider, 1989, Kimball, 2005). Consequently, the ordering of alternatives on ballots is often uniform across electoral districts and non-randomized. This limits researchers to a small pool of locations where variation between districts exists and they can potentially distinguish the primacy effect from other ballot-design characteristics. Additional confounding factors such as other competing selection biases among voters, inconsistent participation among voting populations, and changing electoral rules, can also hinder the ability of researchers to positively associate changes in a candidate's electoral performance with their position on the ballot (Miller \& Krosnick, 1998, Däubler \& Rudolph, 2020). In response to these limitations, scholars have developed an effective research strategy by capitalizing on the few existing locations with favorable electoral rules and observing the primacy effect through natural experiments (Blom-Hansen et. al. 2016, Flis \& Kaminski, 2021). A similar collection of works utilizing controlled laboratory experiments has also developed, though are less common (Johnson \& 
Miles, 2011, Devroe, \& Wauters, 2020). With these approaches, researchers have been able to identify the existence of the primacy effect in a variety of electoral systems, and in both national-level and local elections.

Initial entries into the contemporary literature provided conflicting conclusions on the presence and influence of the primacy effect; with works by Darcy $(1986,1998)$ detecting no appreciable presence, while others such as Lijphart \& López Pintor (1988), and Taebel (1975), finding the effect to be present, but with a relatively modest impact. Despite the initial uncertainty, a common finding among those works that did detect the presence of the primacy effect was that even if the overall percentage of voters influenced was mild, it was enough to have affected the outcomes of many of the observed elections (Hamilton \& Ladd, 1996). Subsequent studies have since been able to consistently find the primacy effect at work in a variety of electoral contexts, ranging from local appointments to representatives for national legislatures (King \& Leigh, 2009, Meredith \& Salant, 2013, Marcinkiewicz, 2014). Additionally, it has been found within a diverse range of electoral systems, with studies in single-member plurality, proportional, and mixed-member systems all showing that being placed first on a ballot boosts electoral success (Faas \& Schoen, 2006, Ho \& Imai, 2008, Marcinkiewicz, 2014, Flis and Kaminski, 2021).

\subsection{Determining the impact on election outcomes and working it down}

With the primacy effect found to operate in a wide variety of electoral settings, the pertinent question that now dominates the literature is in determining the extent of its influence on election outcomes. Results have generally shown the effect to have a highly variable influence; with alternatives receiving between one to fifteen percent increases in votes when placed first on a ballot (Blom-Hansen et. al. 2016, Devroe \& Wauters, 2020, Flis \& Kaminski, 2021); while some others have found hardly any effect at all (Alvarez et. al. 2006). Much of this variability has been traced to the behavioral characteristics that were theorized to make voters susceptible to the effect in the first place, with voters demonstrating a lack of information, greater apathy, and lower cognitive skills being more likely to select the first-placed candidate (Johnson \& Miles, 2011). Other related factors such as the intensity of media coverage and the saliency of an election to a voter have also been found to have a major impact on the primacy effect's influence (Miller \& Krosnick, 1998, Marcinkiewicz, 2014). In down-ballot local elections where popular interest is likely to be lower, studies have found candidates receive substantially more votes when listed first on the ballot (Webber et. al. 2016). In contrast, prominent national elections where information is readily available and interest is high show the primacy effect has an extremely limited impact on the performance of alternatives (Kim et. al., 2015). 
One factor that is often theorized as being a particularly significant influence on the primacy effect is the complexity of elections and the ballot. As ballots become longer and making strategic choices in an election becomes more intricate, voters are more likely to become fatigued and simply vote for the top-ranked alternative out of confusion or exhaustion. An illustrative example of this can be found in Flis and Kaminski (2021), which uniquely provides a comparative study of the primacy effect under multiple local electoral systems within Poland. Their results indicate that while relatively short single member elections exhibited effectively no primacy effect, longer and more complex open-list elections have the potential to provide top-ranked parties an eight percent boost to their vote shares.

The strength and number of findings showing the primacy effect having a powerful influence on electoral outcomes has invariably led scholars to include discussions on how to mitigate the systemic advantages enjoyed by beneficiary alternatives. The most commonly proposed solution has been to introduce greater randomization into the ballot design and distribution process (Klein, \& Baum, 2001, Alvarez et. al. 2006). The rationale being that since it is considered morally suspect and nearSisyphean to force voters to be more informed about elections, it is more feasible to instead reduce the benefit a given alternative receives from the primacy effect by ensuring that they do not systematically show up as the first option. As opposed to a fully randomized process though, proposals usually encourage semi-randomized systems where alternatives appear first in roughly equal proportion (Edwards, 2015, Flis and Kaminski, 2021). This is typically accomplished through the use of some form of chance-based selection process such as generating a randomized alphabet, or holding lotteries to determine alternative listings (Pasek et. al. 2014, Marcinkiewicz, 2014). Such strategies cannot guarantee a complete elimination of the primacy effect, but their use helps roughly ensure that all alternatives benefit.

\section{The Primacy Effect and Mail Voting.}

Alternative voting methods are typically introduced to entice voters to participate in elections by making it more convenient to vote. By-mail voting is particularly appealing to many voters because it eliminates many of the transaction costs to voting and allows users to complete their ballot at a time and place of their choice before election day (Southwell \& Burchett, 2000). Despite its ostensibly broad appeal, these conveniences are disproportionately used by voters who are more educated, politically active and have access to more resources (Alvarez et. al. 2012, 2013). Notably, the same characteristics that make voters likely to use mail ballots closely correspond to those found to reduce a voter's susceptibility to the primacy effect. 
In addition to convenience, by-mail voting also has the potential to influence a voter's access to information when making their decisions. When voting in-person, access to outside information is restricted due to traveling to a designated polling site, limitations on what can be brought into the voting area, and time pressures preventing voters from pausing mid-act to research their options (Karp \& Banducci, 2000). In contrast, by-mail voters can freely choose to conduct additional research on a candidate or position for an extended time before making a decision; providing them additional opportunities to make more informed, or motivated, choices in elections where their political knowledge would otherwise be insufficient. In allowing voters to complete their ballot at their discretion, by-mail voting has the potential to greatly reduce the pressure on voters to decide between candidates or alternatives when information is low or nonexistent; removing one of the key theoretical incentives for voters to be susceptible to the primacy effect. While such observations suggest that the use mail ballots should correspond to a reduced impact of the primacy effect, this relationship has remained underexamined.

Among the existing literature, two articles in particular analyze the interaction between by-mail voting and the primacy effect, but arrive at notably different outcomes. In their 2014 article, Pasek et. al. find only mixed results in the by-mail portion of their study. In contrast, Jankowski and Frank find in their 2021 article that postal voters are significantly less susceptible to the primacy effect.

\subsection{Prevalence and Moderators of the Candidate Name-Order Effect}

In their article, Pasek et. al. (2014) examine all California statewide elections held from 1976 to 2006 to determine the extent to which an array of electoral characteristics that influence the power of the primacy effect. Since 1976, California has required that the order of candidates on ballots be rotated among state assembly districts to help prevent any one candidate systemically benefiting from the primacy effect. This policy has also inadvertently allowed us to observe how much candidates benefit from the primacy effect as their ballot position changes across districts. Consisting of circumstantial electoral characteristics such as public turnout, the prominence of the contested political office, or if the election was partisan, the titular moderators were expected to influence voter behavior through their presence, or absence, and in-turn alter the strength of the primacy effect.

While by-mail voting was only one moderator within their broader study, the article's analysis indicated that a higher number of mail voters reduced the impact of candidate primacy effects, but that this was only present in low-visibility downballot elections such as for the state treasurer or insurer. In more prominent elections for offices such as the president or state governor, the authors found no 
difference in behavior between absentee and in-person voters, indicating that the type of ballot used had no impact. Despite the theoretically greater opportunities to access information, by-mail voters made more informed decisions only in already low-information elections; leading the authors to conclude that the greater number of by-mail voters did not influence the primacy effect.

While the results from Pasek et. al. (2014) suggest that the influence of by-mail voting on the primacy effect is fairly weak, they do notably succeed in identifying a limited relationship between the two that fits with the existing literature's expectations of bymail voter behavior. As previously noted, studies have identified that the influence of the primacy effect generally declines as the salience of an election increases (Klein, \& Baum, 2001). However, the main theorized advantage that mail ballots provide over conventional methods is a greater freedom to access information before voting (Barreto et al. 2006); as the information gap between by-mail and conventional voters closes in high-visibility elections, this advantage should be expected to diminish as well. Additionally, research has also shown that more informed and engaged voters tend to utilize available convenience voting alternatives like voting by-mail (Alvarez et. al. 2012, 2013), but as the proportion of the population using mail ballots increases, this tendency should become less apparent as well.

\subsection{Ballot Position Effects in Open-List PR Systems.}

Jankowski and Frank (2021) explicitly analyzed the 2015 and 2020 elections in the German state of Hamburg to determine if the primacy effect was weaker among by-mail voters. The study was able to separately observe candidate performance among in-person and postal voters due to the ballot boxes in Hamburg each being assigned a unique identification number, with boxes for mail-ballots given numbers two digits longer than election-day boxes. Contrasting the strategy employed in most other studies, ballot positions in the observed elections were not randomized and so the authors instead included individual candidate characteristics and voter selection biases to isolate the effect of mail voting on the primacy effect. Their results first showed that among in-person voters, top placement on the ballot created a sizable electoral advantage; with the top-ranked candidate receiving at-minimum $27 \%$ more votes over lower ranked candidates. The significance of this finding is limited though since most of this effect should be attributed to the fact that parties place their most popular candidates on top of their lists (Marcinkiewicz, 2014). When comparing between in-person and mail voters, they found that the top-ranked candidates experienced a $3 \%$ reduction in their vote share among mail voter. This difference can be attributed to a lower primacy effect and indicates that use of mail-ballots correlates with a sizable reduction of the primacy effect. Additionally, they found 
that this reduction was consistent across ballot positions and that all candidates performed better against the top-ranked candidate among postal voters. Unlike with Pasek et. al. (2014), the results from Jankowski and Frank (2021) indicate that not only is the theorized relationship between mail-voting and the primacy effect present, but that for some voting methods its impact may be stronger than initially assumed.

\section{ConcLusion}

Both studies described above suffer from certain methodological difficulties. The most immediate issue in Pasek et. al. (2014) was that the mail voters were not separated from the total voting population. Thus, the estimates were based on the comparative differences between elections with a high percentage of by-mail voters and those with low percentages. This restricts the utility of their findings since they are ultimately incapable of directly determining if by-mail voters are systematically experiencing the primacy effect in a manner similar to in-person voters. Similarly, the use of aggregate data and non-randomized ballots by Jankowski and Frank (2021) limited the scope of their conclusions to offering only a broad correlation between mail voting and a reduced primacy effect. Both studies were also only able to explore the interaction between mail voting and the primacy effect in the context of one electoral system.

The existing literature has shown that the primacy effect has an appreciable presence in a variety of electoral systems and contexts, with its impact ranging from barely noticeable, to providing a decisive advantage to benefiting candidates. Similarly, alternative voting methods like by-mail voting have been found to greatly alter voter behavior and may also influence how voters process political information. The studies by Pasek et.al. (2014) and Jankowski and Frank (2021) have had limited success in identifying strong causal relationships. Their findings do, however, show promising synergy with existing theories of how mail voting interacts with voters' access to information and provide a useful departure point for future studies.

\section{REFERENCES}

Alvarez, R., Beckett, D., \& Stewart, C. (2013). Voting Technology, Vote-by-Mail, and Residual Votes in California, 1990-2010. Political Research Quarterly, 66(3), 658-670.

Alvarez, R., Levin, I., \& Sinclair, J. (2012). Making Voting Easier: Convenience Voting in the 2008

Presidential Election. Political Research Quarterly, 65(2), 248-262. 
Alvarez, R. M., Sinclair, B., \& Hasen, R. L. (2006). How Much Is Enough? The "Ballot Order Effect" and the Use of Social Science Research in Election Law Disputes. Election Law Journal: Rules, Politics, and Policy, 5(1), 40-56.

Augenblick, N., \& Nicholson, S. (2016). Ballot Position, Choice Fatigue, and Voter Behavior. The Review of Economic Studies, 83(2), 460-480.

Barreto, M., Streb, M., Marks, M., \& Guerra, F. (2006). Do Absentee Voters Differ from Polling Place Voters? New Evidence from California. The Public Opinion Quarterly, 70(2), 224-234.

Binder, M., Childers, M., \& Johnson, N. (2015). Campaigns and the Mitigation of Framing Effects on Voting Behavior: A Natural and Field Experiment. Political Behavior, 37(3), 703-722.

Blom-Hansen, J., Elklit J., Serritzlew S., \& Villadsen L. (2016). Ballot Position and Election Results: Evidence from a Natural Experiment. Electoral Studies, 44, 172-183.

Boehmke, F. J., Branton, R. P., Dillingham, G., \& Witmer, R. C. (2012). Close Enough for Comfort? The Spatial Structure of Interest and Information in Ballot Measure Elections. The Journal of Politics, 74(3), 827-839.

Bonneau, C. W., \& Cann, D. M. (2015). Party Identification and Vote Choice in Partisan and Nonpartisan Elections. Political Behavior, 37(1), 43-66.

Bowler, S., Donovan, T., \& Happ, T. (1992). Ballot Propositions and Information Costs: Direct Democracy and the Fatigued Voter. Western Political Quarterly, 45(2), 559-568.

Brockington, D. (2003). A Low Information Theory of Ballot Position Effect. Political Behavior, 25(1), 1-27.

Darcy, R. (1986). Position Effects with Party Column Ballots. The Western Political Quarterly, 39(4), 648-662.

Darcy, R. (1998). Position Effects in Multimember Districts: The New Hampshire House of Representatives, 1972-1994. Polity, 30(4), 691-703.

Darcy, R., \& Schneider, A. (1989). Confusing Ballots, Roll-Off, and the Black Vote. The Western Political Quarterly, 42(3), 347-364.

Däubler, T., \& Rudolph, L. (2020). Cue-Taking, Satisficing, or Both? Quasi-Experimental Evidence for Ballot Position Effects. Political Behavior, 42(2), 625-652.

Devroe, R., \& Wauters, B. (2020). Does High on the Ballot Means Highly Competent? Explaining the Ballot Position Effect in List-PR Systems. Acta Politica, 55(3), 454-471.

Dubin, J., \& Kalsow, G. (1996). Comparing Absentee and Precinct Voters: A View over Time. Political Behavior, 18(4), 369-392.

Edwards, B. (2015). Alphabetically Ordered Ballots and the Composition of American Legislatures. State Politics \& Policy Quarterly, 15(2), 171-191.

Faas, T., \& Schoen, H. (2006). The Importance of Being First: Effects of Candidates' List Positions in the 2003 Bavarian State Election. Electoral Studies, 25(1), 91-102.

Flis, J., \& Kaminski, M., (2021). Party-related primacy effects in proportional representation systems: Evidence from a natural experiment in Polish local elections. Public Choice, forthcoming.

Grant, D. (2017). The Ballot Order Effect Is Huge: Evidence from Texas. Public Choice, 172(3-4), $421-442$.

Geys, B., \& Heyndels, B. (2003). Ballot Layout Effects in the 1995 Elections of the Brussels' Government. Public Choice, 116(1-2), 147-164. 
Hamilton, J. T., \& Ladd, H. F. (1996). Biased ballots? The impact of ballot structure on North Carolina elections in 1992. Public Choice, 87(3-4), 259-280.

Hansford, T., \& Gomez, B. (2010). Estimating the Electoral Effects of Voter Turnout. The American Political Science Review, 104(2), 268-288.

Ho, D., \& Imai K. (2008). Estimating Causal Effects of Ballot Order from a

Randomized Natural Experiment: The California Alphabet Lottery, 1978-2002. Public Opinion Quarterly, 72(2), 216-240.

Jankowski, M., Frank, T. (2021). Ballot Position Effects in Open-List PR Systems: The Moderating Impact of Postal Voting. Acta Politica, 1-22.

Johnson, A., \& Miles, C. (2011). Order Effects of Ballot Position without Information-Induced Confirmatory Bias. British Politics, 6(4), 479-90.

Karp, J., \& Banducci, S. (2000). Going Postal: How All-Mail Elections Influence Turnout. Political Behavior, 22(3), 223-239.

Klein, D., \& Baum, L. (2001). Ballot Information and Voting Decisions in Judicial Elections. Political Research Quarterly, 54(4), 709-728.

Kim, N., Krosnick, J., \& Casasanto, D. (2015). Moderators of Candidate Name-Order Effects in Elections: An Experiment. Political Psychology, 36(5), 525-542.

Kimball, D. (2005). Ballot Design and Unrecorded Votes on Paper-Based Ballots. Public Opinion Quarterly, 69(4), 508-529.

Kimball, D., \& Kropf, M. (2005). Ballot Design and Unrecorded Votes on Paper-Based Ballots. The Public Opinion Quarterly, 69(4), 508-529.

King, A., \& Leigh, A. (2009). Are Ballot Order Effects Heterogeneous? Social Science Quarterly, 90(1), 71-87.

Koppell, J. G., \& Steen, J. A. (2004). The Effects of Ballot Position on Election Outcomes. The Journal of Politics, 66(1), 267-281.

Lijphart, A., \& López Pintor, R. (1988). Alphabetic bias in partisan elections: Patterns of voting for the Spanish Senate, 1982 and 1986. Electoral Studies, 7(3), 225-231.

Lutz, G. (2010). First Come, First Served: The Effect of Ballot Position on Electoral Success in Open Ballot PR Elections. Representation, 46(2), 167-181.

Marcinkiewicz, K. (2014). Electoral Contexts That Assist Voter Coordination: Ballot Position Effects in Poland. Electoral Studies, 33, 322-34.

Matson, M., \& Fine, T. S. (2006). Gender, Ethnicity, and Ballot Information: Ballot Cues in Low-Information Elections. State Politics \& Policy Quarterly, 6(1), 49-72.

Meredith, M., \& Salant, Y. (2013). On the Causes and Consequences of Ballot Order Effects. Political Behavior, 35(1), 175-197.

Miller, J., \& Krosnick, J. (1998). The Impact of Candidate Name Order on Election Outcomes. Public Opinion Quarterly, 62(3), 291-330.

Niemi, R., \& Herrnson, P. (2003). Beyond the Butterfly: The Complexity of U.S. Ballots. Perspective on Politics, 1(02), 317-326.

Pasek, J., Schneider, D., Krosnick, J., Tahk, A., Ophir, E., \& Milligan, C. (2014). Prevalence and Moderators of the Candidate Name-Order Effect. Public Opinion Quarterly, 78(2), 416-439.

Patterson, S., \& Caldeira, G. (1985). Mailing In the Vote: Correlates and Consequences of Absentee Voting. American Journal of Political Science, 29(4), 766-788. 
Pierzgalski, M., Górecki M., \& Stępień, P. (2020). Ballot Paper Design and Vote Spoiling at Polish Local Elections of 2014: Establishing a Causal Link. East European Politics and Societies, 34(3), 611-636.

Selb, P. (2008). Supersized votes: Ballot length, uncertainty, and choice in direct legislation elections. Public Choice, 135(3-4), 319-336.

Shugart, M., Valdini, M., \& Suominen, K. (2005). Looking for Locals: Voter Information Demands and Personal Vote-Earning Attributes of Legislators Under Proportional Representation. American Journal of Political Science, 49(2), 437-449.

Southwell, P., \& Burchett, J. (2000). Does Changing the Rules Change the Players? The Effect of All-Mail Elections on the Composition of the Electorate. Social Science Quarterly, 81(3), 837-845.

Taebel, D. (1975). The Effect of Ballot Position on Electoral Success. American Journal of Political Science, 19(3), 519-536.

Van Erkel, P., \& Thijssen, P. (2016). The First One Wins: Distilling the Primacy Effect. Electoral Studies, 44, 245-254.

Verba, S., Schlozman, K., \& Brady, H. (1995). Voice and Equality: Civic Voluntarism in American Politics. Cambridge, MA: Harvard University Press.

Wand, J., Shotts, K., Sekhon, J., Mebane, W., Herron, M., \& Brady, H. (2001). The Butterfly Did It: The Aberrant Vote for Buchanan in Palm Beach County, Florida. American Political Science Review, 95(4), 793-810.

Webber, R., Rallings, C., Borisyuk, G., \& Thrasher, M. (2014). Ballot Order Positional Effects in British Local Elections, 1973-2011. Parliamentary Affairs, 67(1), 119-136. 